\title{
MELOS: UMA PROVA RETÓRICA NAS CANÇÕES EM PERSPECTIVA SEMIÓTICA
}

\author{
MELOS: A RHETORIC PROOF IN SONGS \\ IN SEMIOTIC PERSPECTIVE
}

\author{
Adriano Dantas de Oliveira* \\ Universidade Federal do Recôncavo da Bahia, Santo Amaro, BA, Brasil
}

Resumo: Teremos, neste trabalho, a exposição de uma abordagem ao texto cancional como uma situação retórica espećfíca. Evidenciaremos a melos, assimilada como todos os aspectos musicais da canção, como uma prova retórica que se articula à tradicional trilogia: ethos, logos e pathos. Dessa forma, abordaremos, discursivamente, a maneira como os elementos musicais de uma canç̃̃o podem funcionar como recursos persuasivos. Utilizaremos um arcabouço teórico interdisciplinar, articulando a retórica clássica à semiótica aplicada à canção. Como corpus, teremos a análise de uma amostragem de canções buarquianas de temática sócio-política composta e gravada durante o período da ditadura.

Palavras-chave: Melos, Ethos; Logos, Pathos; Canção.

Abstract: We will have, in this work, the exposure of an approach to cancional text as a specific rhetorical situation. We assimilated the melos as all musical aspects of the song as a rhetorical proof that articulates the traditional trilogy: ethos, logos and pathos. We will use an interdisciplinary theoretical framework, articulating the classical ihetoric to semiotics applied to the song, exploring, from this model, discursive aspects of cancional text. As corpus, we have the analysis of a buarquiana song sample sociopolitical theme composed and recorded during the period of dictatorship.

Keywords: Melos; Ethos; Logos; Pathos; Canção.

* Professor Doutor da Universidade Federal do Recôncavo da Bahia - UFRB, Santo Amaro, BA, Brasil; adrianodeoliveira_@hotmail.com 
Linha D'Água (Online), São Paulo, v. 29, n. 2, p. 221-245, dez. 2016

\section{Introdução}

Neste trabalho, analisamos uma amostragem de canções buarquianas do período da ditadura militar brasileira com temática sociopolítica. Consideramos que este período, devido à opressão e à repressão em relação à manifestação de opiniões, foi permeado e delineado por tensões e por controvérsias, sobretudo no âmbito discursivo. Destaquemos ainda que no contexto, temos por meio de diversas canções da época um espaço discursivo de resistência e de manifestações acerca de temas cerceados ou proibidos por mecanismos diversos. Podemos associar esses mecanismos de controle e de rarefação do discurso à "vontade de verdade" ou à "palavra proibida" postuladas por Foucault (2012 [1971]) ou também aos "aparelhos ideológicos do estado" postulados por Althusser (1985). Retomemos o que afirma Foucault (2012 [1971], p. 10) “[...] Por mais que o discurso seja aparentemente bem pouca coisa, as interdições que o atingem revelam logo, rapidamente, sua ligação com o desejo e com o poder [...]”. E acrescenta: “[...] o discurso não é simplesmente aquilo que traduz as lutas ou os sistemas de dominação, mas aquilo por que se luta, o poder do qual nos queremos apoderar." Assim, destaquemos as sobredeterminações em todas as instâncias de produção do discurso, sendo ele estruturado pelas relações de poder e estruturante delas. É nesse espaço de tensão e de controvérsia que acreditamos inserirem-se as canções buarquianas por nós selecionadas. Percebemos, dessa forma, no corpus analisado, sua dimensão retórica ao tratar de temas como "opressão versus liberdade" e a mobilização de paixões a partir desses temas na relação com o estado de coisas exposto ao assentimento.

Em relação à abordagem do corpus, nós o consideramos como uma manifestação artística popular, uma prática associada a um projeto final. Cabe destacar que a canção tem sua letra organizada musicalmente, considerando a melos, aqui assimilada como todos os elementos musicais que se sincretizam à letra e que padronizam e estabilizam as entoações - as alturas das sílabas musicais dos versos da canção (as unidades entoativas). Dessa forma, consideramos, no âmbito da melos a tonalidade, o timbre, aspectos harmônicos da modulação vocal e instrumental; o andamento, o ritmo, a celeridade; as entoações e suas alturas; a densidade musical etc. Essa abordagem da melos justifica-se, pois, em nosso corpus, além da letra, concorrem diversos 
Linha D'Água (Online), São Paulo, v. 29, n. 2, p. 221-245, dez. 2016

elementos que se sincretizam, engendrando efeitos de sentido e servindo a propósitos comunicativo-persuasivos, como pudemos perceber em nossas análises.

Assim, o texto cancional possui uma complexidade de abordagem singular e convoca uma fundamentação teórica interdisciplinar capaz de analisar as grandezas linguísticas e as não linguísticas que se articulam em seu plano da expressão. Utilizamos, então, como arcabouço teórico, conceitos da semiótica discursiva e da semiótica aplicada à canção e associamos as categorias depreendidas à retórica. Verificamos, assim, em que medida a melos opera como mais uma prova de persuasão articulada à trilogia retórica.

\section{Retórica}

Data do século V a.C. o surgimento da retórica e tem como seu primeiro tratado, conforme os estudos de Fonseca (2001), a Teoria Retórica de Córax e Tísias, cujo aparecimento se dá em Siracusa, cidade grega que, na época, se destacava por seu poder econômico e cultural. Essa cidade ficava situada nas planícies da ilha da Sicília, Sudoeste do que hoje conhecemos como Península Itálica. O surgimento da retórica é oriundo de uma intervenção concreta do indivíduo em seu meio social por meio da linguagem.

Por volta de 485 a.C, dois tiranos sicilianos [...] foram destronados por efeito de uma sublevação democrática, a reposição da ordem levou o povo à instauração de inúmeros processos que mobilizaram grandes júris populares e obrigaram os intervenientes a socorrerem-se das suas faculdades orais de comunicação. [...] Foi nesse decisivo momento histórico em que a democracia se impôs à tirania, precisamente no tempo em que conheceu Péricles, que Córax e Tísias de Siracusa conceptualizaram e publicaram o primeiro manual de retórica (ALEXANDRE JÚNIOR, 1998, p. 13-14).

Para Meyer (2007), a retórica clássica está fundamentada em três filósofos: Platão, Quintiliano e Aristóteles, e a nova retórica tem como primeiro representante Chaim Perelman, com a publicação do Tratado da Argumentação (1958). Temos, conforme o autor, as seguintes concepções para a retórica clássica “(1) A Retórica é uma manipulação do auditório (Platão); (2) a Retórica é a arte de bem 
Linha D'Água (Online), São Paulo, v. 29, n. 2, p. 221-245, dez. 2016

falar (Quintiliano); (3) a Retórica é a exposição de argumentos ou de discursos que devem ou visam persuadir (Aristóteles)" (MEYER, 2007, p. 21). Acerca da (4) Nova Retórica, a partir do Tratado da Argumentação, podemos dizer que está centrada no uso e no "estudo das técnicas discursivas para provocar ou aumentar a adesão dos espíritos às teses que se lhes apresentam ao assentimento" (PERELMAN \& OLBRECHTS-TYTECA, 2005, p. 4). Essas concepções distintas mostram que a retórica é o terreno da disputa, da controvérsia, do conflito, mesmo quando o objeto de discussão é sua própria definição.

\subsection{Trilogia retórica}

Todo o sistema retórico estudado e desenvolvido por Aristóteles possui como base uma tríplice formação: ethos $(\hat{\eta} \theta 0 \zeta)$ - imagem do orador, de onde partem escolhas e atitudes; pathos ( $\pi \alpha \theta$ o $\zeta)$ - plateia ou audiência, de onde são suscitadas e mobilizadas paixões; logos $(\lambda \circ \delta \circ \zeta)$ - saber e discurso, aquilo que se coloca como questão a ser tratada na situação retórica. Sobre ethos, logos e pathos, podemos dizer que se estabelece uma relação mútua e recíproca entre eles, isolável apenas para reconhecimento e análise, pois em uma situação retórica os elementos dessa trilogia funcionam imbricados, aquele que fala constitui e é constituído por aquele que ouve, por meio de representações recíprocas e daquilo que é tratado. Assim, em retórica clássica, Aristóteles define três tipos de provas técnicas ou artísticas de persuasão: "umas residem no caráter moral do orador; outras no modo como se dispõe o ouvinte; e outras, no próprio discurso, pelo que este demonstra ou parece demonstrar" (ARISTÓTELES, 1998 [s/d], p. 49).

Ressaltemos que ethos é uma prova não proposicional, sobre a qual Aristóteles conceitua que

[...] persuade-se pelo caráter quando o discurso é proferido de tal maneira que deixa a impressão de o orador ser digno de fé [...] é, porém, necessário que esta confiança seja resultado do discurso e não de uma opinião prévia sobre o caráter do orador. (idem, p. 49).

Desse modo, o orador assume um caráter para chamar a atenção e conseguir credibilidade a fim de mobilizar, sensibilizar o pathos do auditório, suas tendências 
e suas emoções, e conduzi-lo a uma determinada perspectiva, colocando seu próprio ponto de vista com o objetivo de obter adesão.

O ethos, para Aristóteles, caracteriza-se como fonte de credibilidade e consequentemente como prova retórica a partir de três elementos: a phronesis, a arete e a eunoia. "Três são as causas que tornam persuasivos os oradores e a sua importância é tal que por ela persuadimos, sem necessidades de demonstrações. São elas a prudência, a virtude, e a benevolência" (ARISTÓTELES, 1998 [s/d] p. 106). Embora esses elementos estejam relacionados ao ethos, à imagem do orador, eles fazem referência também ao pathos e ao logos.

Segundo Eggs (2005, p. 40), Aristóteles, ao mencionar a prudência/sabedoria (a phronesis), refere-se ao que provoca a confiança no auditório, assim, ela se evidencia quando o orador apresenta argumentos sábios e razoáveis, elementos que remetem ao logos; a virtude (a arete) evidencia-se quando o orador aparenta argumentar sincera e honestamente e está mais intimamente ligada ao ethos; a benevolência (a eunoia) evidencia-se quando o orador mostra-se solidário e amável em relação aos seus ouvintes, o que remete mais diretamente ao pathos.

O segundo tipo de prova, também não proposicional, vincula-se à disposição do auditório, ou seja, às emoções, às paixões que o discurso e o orador o levam a experimentar “[...] a paixão é um reservatório para mobilizar o auditório em favor de uma tese. Isso reforça a identidade dos pontos de vista, ou a diferença em relação à tese que procuramos afastar" (MEYER, 2007, p. 38). Assim, "É o que o enraivece, o que ele aprecia, o que ele detesta, o que ele despreza, ou contra o que se indigna, o que ele deseja, e assim por diante, que fazem do pathos do auditório a dimensão retórica do interlocutor" (MEYER, 2007, p. 39). Em retórica clássica temos catorze grandes paixões: a cólera, a calma, o temor, a confiança, a inveja, a impudência, o amor, o ódio, a vergonha, a emulação, a compaixão, o favor (obsequiosidade), a indignação e o desprezo. Na perspectiva aristotélica, as paixões manifestam-se em relação àquilo que se coloca em questão, o "não eu" a que nos projetamos.

A terceira prova de persuasão, o logos, é caracterizada como uma prova proposicional, relacionada ao que é construído por meio da razão e do discurso. Conforme Meyer (2007, p. 45), em retórica clássica, o logos é tudo aquilo que está em questão na situação retórica, não se refere apenas ao texto, mas ao que se propõe 
Linha D'Água (Online), São Paulo, v. 29, n. 2, p. 221-245, dez. 2016

tratar. "Aquilo que o texto diz e também as questões a que o texto responde, suscita ou trata de alguma forma". Assim: "Para que haja Retórica, é preciso que uma questão seja levantada e permaneça, a despeito do que soluciona, ou em razão da resposta que soluciona" (MEYER, 2007, p. 62). A relação constituída em uma situação retórica na qual a trilogia exposta se imbrica, se toca e se articula de forma recíproca pode ser representada da seguinte forma:

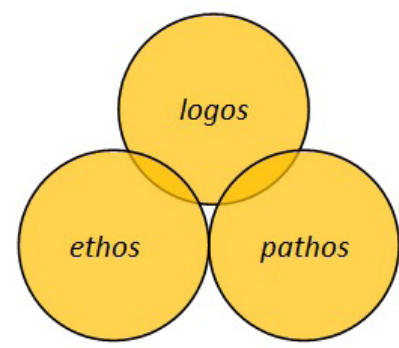

Figura 1: Situação retórica - articulação da trilogia retórica

Fonte: Oliveira (2013, p. 05).

\section{Semiótica}

A análise da linguagem é de extrema relevância para que se chegue a sua discursividade, compreendida neste trabalho como os aspectos subjacentes ao texto. Essa perspectiva coloca em evidência os efeitos de sentido que os textos verbais e não verbais suscitam. A problemática se intensifica uma vez que os textos manifestam-se sob diversos gêneros. Assim, a noção de texto torna-se abrangente e, sua abordagem, ainda mais complexa, tendo em vista as necessidades das inúmeras situações de comunicação existentes no mundo atual, bem como a necessidade artística e cultural inerente ao ser humano.

A semiótica discursiva inscreve-se na problemática de estudos da língua e da linguagem, do texto e do discurso subjacente a ele. A vertente semiótica, a partir da qual nos pautamos neste trabalho, constitui-se como um projeto de ciência, desenvolvido inicialmente pelo lexicólogo lituano Algirdas Julien Greimas e pelo Grupo de Investigações Semiolinguísticas da Escola de Altos Estudos em Ciências Sociais. Essa teoria, pertencente ao estruturalismo francês, é bastante pertinente à análise pretendida pelo seu objetivo de buscar os possíveis efeitos de sentido em um texto, seja ele verbal, não verbal ou sincrético. 
Linha D'Água (Online), São Paulo, v. 29, n. 2, p. 221-245, dez. 2016

Em 1966, Greimas publica o livro Semântica Estrutural, inaugurando procedimentos de análise e de estudo do texto, assimilando-o como unidade de sentido e tornando o sentido da frase subordinado a essa unidade. Com a semiótica, inauguram-se procedimentos de análise, cujo ponto de partida é o texto. Temos, desse modo, a ideia de uma abordagem ao sentido além da frase, passando de uma abordagem linguística para uma abordagem semiótica. Assim, Greimas cria uma sintaxe da narratividade. "[...] em vez de noções linguísticas, o autor estava agora operando com noções semióticas.” (TATIT, 2003, p. 188).

A partir dessa abordagem, torna-se central a noção de efeitos de sentido, a qual traz importantes contribuições aos estudos linguísticos: a conclusão de que o sentido é um dos elementos imprescindíveis à análise da linguagem em todos os seus aspectos.

Utilizamos, no recorte deste trabalho, nos momentos de análise, categorias da semiótica greimasiana, ou semiótica discursiva e também os desdobramentos da semiótica, sobretudo, da semiótica aplicada à canção que expomos a seguir.

\subsection{Semiótica aplicada à canção}

Desde a sua idealização, a semiótica passou por diversos desdobramentos para dar conta de seus objetivos, um deles é a semiótica aplicada à canção.

A canção segundo os postulados de Tatit (1996, p. 11-12), tem a melodia cantada, possivelmente, com origem na gestualidade da fala, ou seja, em aspectos da fala cotidiana em uso, considerando as entoações - ascendentes ou descendentes; as pausas; as modulações etc. Destaca, ainda, que a canção popular possui uma espontaneidade enunciativa que faz com que sua letra se submeta aos contornos melódicos. Podemos, assim, assimilar que, em um texto cancional, ocorre uma articulação entre princípios prosódicos e melódicos. Dessa forma, é necessário assimilar, na canção, aspectos típicos da fala e da prosódia, uma vez que mesmo havendo um modelo de previsibilidade e de estabilidade melódica não há a necessidade de uma padronização coerciva em relação à construção das frases, dos versos ou das unidades entoativas (células do nível das alturas da entoação) em uma canção. 
Linha D'Água (Online), São Paulo, v. 29, n. 2, p. 221-245, dez. 2016

O gênero canção, em sua constituição, apresenta-se de forma bastante complexa, considerando aspectos literários, poéticos, rítmicos, melódicos, prosódicos, harmônicos, de densidade, timbrísticos etc. Todos esses aspectos devem ser considerados em uma análise, pois são também suscitadores de efeitos de sentido. Carmo Jr. (2003, p. 223) ratifica essa afirmativa ao postular que a canção "possui características tensivas típicas da prosódia, razão pela qual a melodia pode ser dotada de sentido". Então, uma análise discursiva de uma canção que considere apenas a letra mostra-se incompleta, pois letra, melodia, harmonia, ritmo, densidade, entre outros, são elementos que se sincretizam na canção, suscitam, juntos, efeitos de sentido específicos.

\section{Frase, unidades entoativas e tonemas}

Conforme os estudos de Tatit (1994), as unidades entoativas são unidades do nível da célula na melodia, uma unidade mínima entoada em determinada altura na tessitura musical. Trata-se, assim, de uma "sílaba musical". O nível superior, nesse sentido, é a frase musical, constituída por um conjunto de unidades entoativas e que tem seu fim demarcado por um tonema (unidade entoativa que finaliza a frase). A fim de ilustrarmos essa explanação, observemos o diagrama a seguir com a exposição de um trecho da canção buarquiana "Acorda, amor" de 1974, conforme as alturas das entoações:

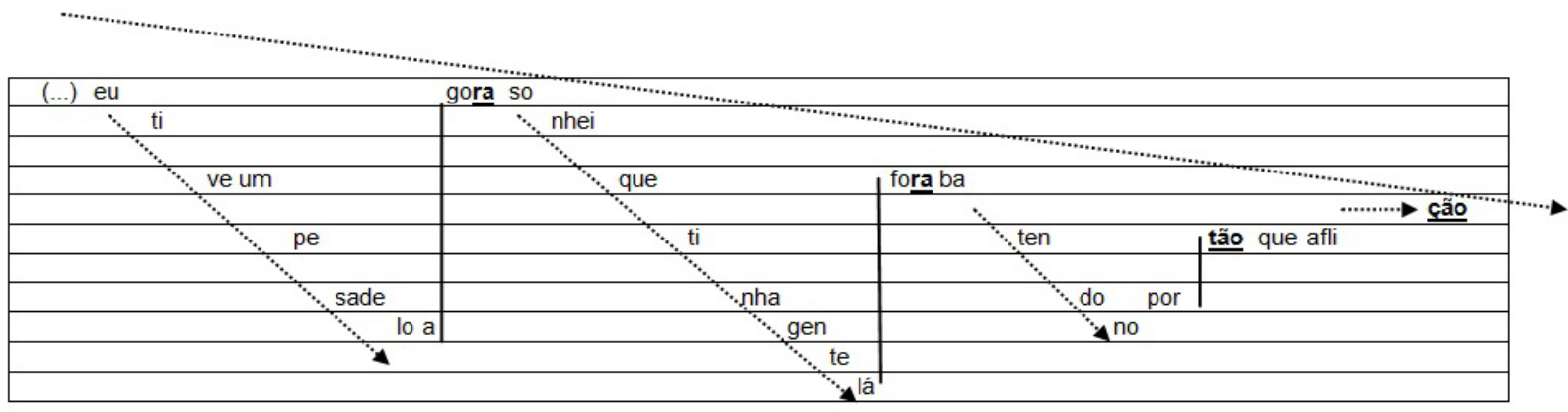

Figura 2: diagrama - exemplo das unidades entoativas e dos tonemas 
Temos, conforme o diagrama exposto, as unidades entoativas distribuídas pela tessitura musical, o campo das alturas dividido em meio tom, as sílabas do nível da entoação. Em negrito, destacamos os tonemas (unidades entoativas finais) que marcam o final de cada frase musical e as setas indicando a direção, a tendência ascendente ou descendente da entoação. Convém ressaltar que a direção descendente da fala, prosodicamente, indica a asseveração, a afirmação. A direção ascendente, por sua vez, indica a prossecução, a indagação, a suspensão. Essas características prosódicas também podem ser consideradas na análise cancional.

\subsection{Formas de integração letra e melodia}

Sobre os modos de integração entre letra e melodia, temos três maneiras distintas de ocorrência: a figurativização, a tematização e a passionalização (ou desdobramento).

A figurativização é uma forma de integração da letra à melodia com uma tendência maior à aproximação da gestualidade da fala. Sobre esse modo de integração, temos que é “[...] uma espécie de integração 'natural', entre o que está sendo dito e o modo de dizer, algo bem próximo de nossa fala cotidiana de emitir frases entoadas [...]" (TATIT e LOPES, 2008, p. 17). De acordo com os autores, tudo que enunciamos em nossa língua já vem com uma melodia própria típica da prosódia. Dessa forma, a criação desse simulacro no interior da canção é chamado de efeito figurativo da locução (idem, p. 17-18). Ainda conforme Tatit (1997, p. 118-120), a figurativização é uma construção em que há um processo de distensão, de desinvestimento do percurso melódico, buscando ser mais próxima da gestualidade da fala, mais entoativa.

Sobre a tematização, um segundo modo de integração da letra à melodia, consideremos que é um modo típico da conjunção, da identidade, da celebração, da euforia. "[...] Na letra, exalta-se a mulher desejada, a terra natal, a dança preferida, o gênero musical, uma data, um acontecimento [...]", dessa maneira, esses conteúdos da letra manifestam-se na melodia com a "[...] aceleração do andamento, valorização dos ataques consonantais e acentos vocálicos (consequentemente, redução das durações) e procedimentos de reiteração [...]” (TATIT e LOPES 2008, 
p. 18-19). Conforme os autores, a letra "ressoa" nos motivos melódicos. Assim, temos um desenvolvimento melódico da conjunção, da identidade. Nesse modo de integração, o campo de tessitura da melodia se mostra restrito, apropriado para um modelo melódico horizontalizado.

Um terceiro modo de integração é a passionalização que se caracteriza por uma verticalização na exploração do uso da tessitura musical, por um prolongamento das unidades entoativas e por uma consequente desaceleração no andamento da melodia "[...] Na letra, temos em geral a descrição dos estados passionais que acusam a ausência do outro, o sentimento (presente, passado ou futuro) de distância, de perda, e a necessidade de reconquista [...]”. Temos assim, uma integração caracterizada pela busca, pela disjunção, pela alteridade, enfim, pela passionalização e, nesse modelo

[...] manifestam-se direções que exploram amplamente o campo de tessitura (de praxe, mais dilatado), servindo-se mais uma vez de decisões musicalmente complementares: desaceleração do andamento, valorização das durações vocálicas, sobretudo para definir os pontos de chegada [...] (TATIT e LOPES 2008, p. 21).

Conforme os autores esse modelo de integração ressalta a distância do sujeito em relação ao seu objeto (aquilo que ele deseja estar em conjunção) e essa distância se converte em percurso melódico.

Essas três formas de integração são bastante regulares no universo cancional e se combinam e se articulam nas canções. Assim, para caracterizar uma canção como baseada em uma forma de integração ou outra, é necessário observar a predominância desses modos, pois em uma mesma canção podemos ter dois ou mais modos de integração presentes.

Outra forma pela qual a tensão pode ser modulada nas frases musicais, e que consideramos em alguns pontos de nossa análise, é pela harmonia. Nesse âmbito, temos elementos como a tonalidade da canção - maior ou menor; os acordes que dão base à entoação - no que tange à configuração do acorde dissonantes ou não, maior ou menor, gerando um efeito de tensão ou de resolução na configuração musical, enfim, elementos da harmonia, os quais, no texto cancional, produzem 
Linha D'Água (Online), São Paulo, v. 29, n. 2, p. 221-245, dez. 2016

efeitos de tensão e de expectativa, ou de distensão e de resolução, que podem ser relacionados a uma alteridade ou a uma identidade no âmbito musical.

\section{A trilogia retórica associada à melos como quarta prova de persuasão}

Conforme demonstramos, na abordagem de uma situação retórica cancional, devem-se considerar, na articulação da trilogia retórica, aspectos musicais inerentes à canção. A entoação, a harmonia, o ritmo, a densidade musical, entre outros aspectos musicais, servem a propósitos comunicativos ao se sincretizarem à letra, potencializando as provas retóricas de persuasão: ethos, logos e pathos. Neste trabalho, categorizamos os elementos musicais depreendidos nas análises como a melos, um quarto elemento que se apresenta no texto cancional. Sobre a natureza da melos, aspecto inerente à canção, além do que já expusemos, podemos acrescentar o que postula Valery (1991) ao diferenciar o universo musical dos ruídos.

[...] Nesta sala em que estou falando, onde vocês ouvem o ruído de minha voz, se um diapasão ou um instrumento bem afinado começasse a vibrar, imediatamente, assim que fossem afetados por esse ruído excepcional e puro que não pode ser confundido com os outros, vocês teriam a sensação de um começo, o começo de um mundo; uma atmosfera diferente seria imediatamente criada, uma nova ordem seria anunciada, e vocês mesmos se organizariam inconscientemente para acolhê-la. [...] (VALERY, 1991, p. 210).

Assim, Valery (1991) postula que o som musical difere-se do ruído tal qual a ordem da desordem. Surge, desse modo, o conceito de música. A música instaura uma atmosfera ao que Valery chama de "universo musical". E, dessa forma, "[...] o músico se encontra em posse de um sistema perfeito de melos bem definido, que fazem com que sensações correspondam exatamente a atos. [...]" (VALERY, 1991, p. 210).

Entendemos que a parte musical das canções constitui um campo vasto de sentidos e de relevância, sobretudo ao assimilarmos as canções como uma situação retórica que trata de alguma questão específica. Consideremos, ainda, que é no "universo musical" a ser acolhido pelo ouvinte que a situação retórica instaura-se. 
Linha D'Água (Online), São Paulo, v. 29, n. 2, p. 221-245, dez. 2016

Outro fator relevante, ainda, conforme Valéry (1991, p. 208), versa sobre o uso da linguagem associado a uma prática, quando essa prática produz seu efeito, a linguagem em seu plano de expressão se desfaz: "Eu peço fogo a vocês. Vocês me dão fogo". Nas palavras do autor, "desfaz-se na clareza" (idem, 208), pois, cumpriu aquilo que deveria ter cumprido. Dessa maneira, a linguagem, quando tem por objetivo apenas ser compreendida, é substituída por seu sentido e o plano de expressão tal como foi constituído deixa de existir e dá lugar à compreensão. Temos nesses postulados a noção oposta no universo poético. Para Valery (1991, p. 213) o poema não morre por ter vivido, pois é feito para ser retomado, em sua expressão, sem alterações, para "[...] renascer de suas cinzas e vir a ser indefinidamente o que acabou de ser. A poesia reconhece-se por esta propriedade: ela tende a se fazer reproduzir em sua forma, ela nos excita a reconstituí-la identicamente." Assim, ao referir-se ao universo poético, a linguagem ganha outros contornos que vão além de sua função pragmática comum. Podemos relacionar o que Valery postula sobre o universo poético à canção, uma vez que o texto cancional compartilha muitas características com a poesia. Citemos, além de sua organização em versos e em estrofes, a sua regularidade como plano de expressão pronta a ser retomada (letra, entoação e melodia).

Destaquemos, ainda, que a melodia de uma canção opera como um dispositivo mnemônico, uma vez que uma canção pode ser, em geral, mais facilmente memorizada do que um texto em prosa por exemplo. As entoações estabilizadas pela melos favorecem a memorização, propiciando a sua reiteração, seja em um cantarolar ou na presentificação da canção na memória.

Dessa forma, tomamos a melos como uma prova retórica que se articula à trilogia retórica como um fator de persuasão que toca o ethos, o logos e o pathos. 
Linha D'Água (Online), São Paulo, v. 29, n. 2, p. 221-245, dez. 2016

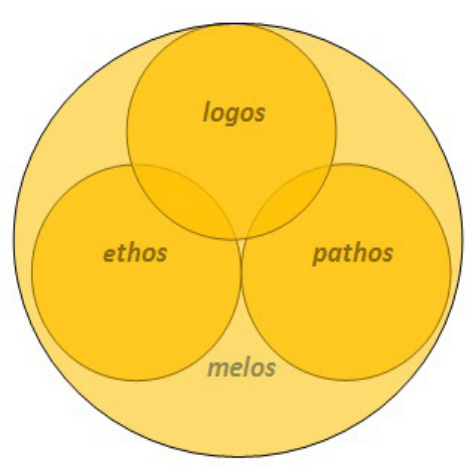

Figura 3: Articulação da trilogia retórica associada à melos

Fonte: Oliveira (2014, p. 15).

\section{Análise de canções: a melos articulada à trilogia retórica}

\section{1 "Bom tempo" - Logos e Melos}

Iniciaremos a nossa demonstração da melos como prova de persuasão articulada à trilogia retórica com a análise da canção “Bom tempo" de 1968/69.

Convém destacar preliminarmente o título da canção, a proposição da deliberação acerca do futuro. Percebemos, já no título, um isotopante, um núcleo a ser recoberto figurativamente por temas que serão expostos na canção. Ocorre, também, uma construção figurativa baseada em uma recção semântica: a palavra “tempo" está reccionada a "bom”. O procedimento deixa uma suspensão temática: trata-se de um clima, meteorologicamente melhor ou de uma época melhor. Em oposição ao título, temos também a pressuposição da existência de um "mau tempo". Passemos à integração entre letra e melodia nos primeiros versos: 
Linha D'Água (Online), São Paulo, v. 29, n. 2, p. 221-245, dez. 2016

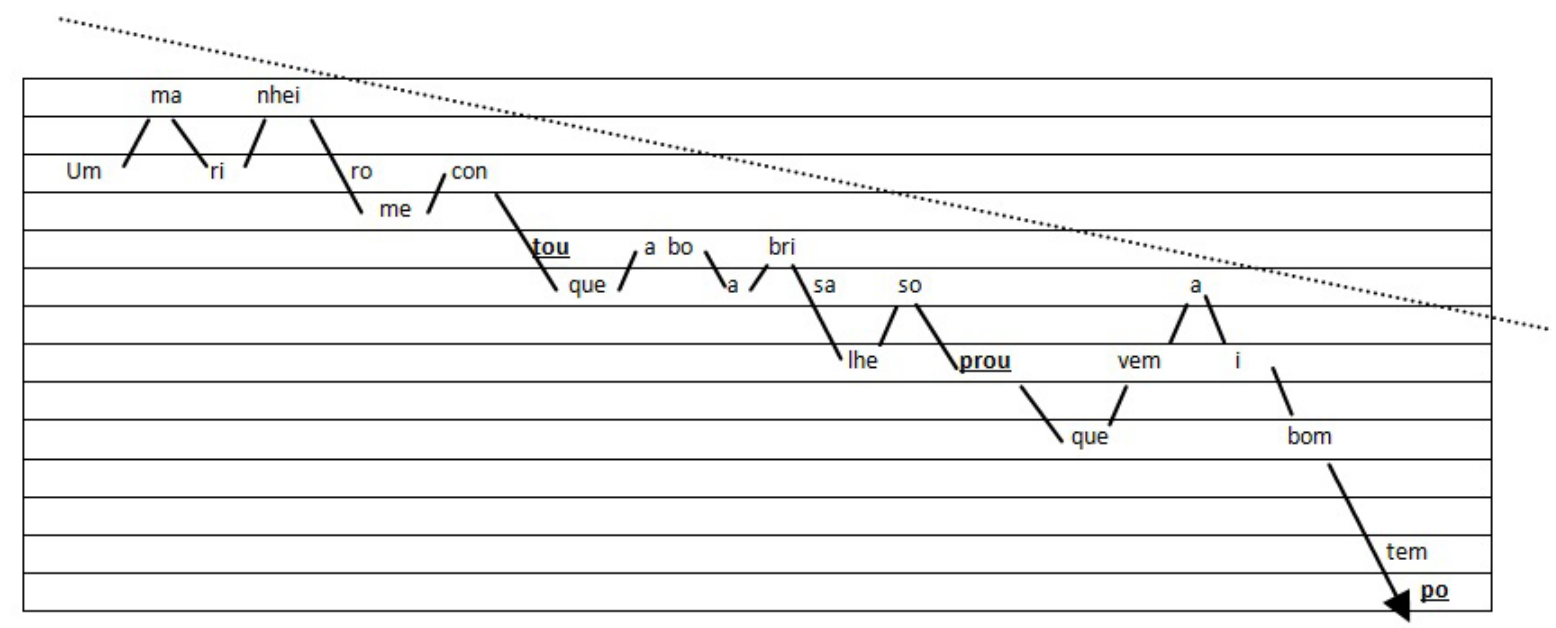

Figura 4

Ocorre, no início da canção, uma curva melódica descendente, uma gradação em graus marcados, terminando por um tonema em posição mais grave. Esse procedimento enfatiza a asseveração do anúncio da boa nova. Observamos que, acerca do modo de integração letra versus melodia, temos um regime baseado na passionalização. As unidades entoativas prolongadas e um andamento desacelerado da melodia configuram uma busca, caracterizando uma falta. Temos, então, um sujeito, em nosso caso o próprio orador, na relação com a falta de seu objeto, o "bom tempo".

Observamos que o orador instala-se no texto pela marca do pronome pessoal "me" mantida por toda a canção, figura de presença que traz à memória do auditório a imagem do orador, que, juntamente com seu ouvinte, constitui-se pela falta, na disjunção e na busca por um objeto-comum: o "bom tempo". No mesmo modelo melódico exposto, temos, então, os versos seguintes: "Um marinheiro me contou/ Que a boa brisa lhe soprou/ Que vem aí bom tempo/ Um pescador me confirmou/ Que o passarinho lhe cantou/ Que vem aí bom tempo"

Assim, o orador procura fornecer um "saber" adquirido ao auditório. Há no simulacro criado, a construção de uma realidade no âmbito discursivo, uma notícia que circula sobre a iminência do bom tempo, a deliberação sobre o futuro. As fontes que dão ao orador esse "saber", possuem um traço comum de pertinência: a itinerância, visto que "pescador", "marinheiro", "passarinho" e "boa brisa” possuem como 
Linha D'Água (Online), São Paulo, v. 29, n. 2, p. 221-245, dez. 2016

característica comum o fato de estarem constantemente viajando, circulando e possuírem, por consequência, mais conhecimento sobre o clima que virá sobre a costa.

Destaca-se também na canção a isotopia, rede de elementos, que, encadeados, tematizam algo, constituída pela reiteração da proposição deliberativa "Que vem aí bom tempo" com a configuração melódica passional e asseverativa, anunciando a movimentação do objeto sobre o orador e sobre o auditório. Destaquemos que este objeto comum opera também como uma figura de comunhão, uma vez que coloca tanto orador como auditório com um traço de identidade, pertencentes a um grupo que se reconhece pelo "bem comum", anunciado em um devir reiterado asseverativamente, em uma curva descendente, tipicamente de frases declarativas na prosódia. Dessa forma, temporal e espacialmente o objeto está na iminência do devir, como um sobrevir, vir repentina e abruptamente, e o orador-sujeito prepara seu auditório-sujeito para a chegada do referido objeto.

No âmbito da melos, temos a passionalização como predominância, porém articulada à figurativização e à tematização, conforme iremos observar. Melodicamente, temos um movimento de transição, preparando a mudança no modo de integração da passionalização para outros modos de integração, como observaremos nos dois próximos diagramas.

Assim, ocorre uma integração ainda sob o mesmo regime, porém com um desinvestimento melódico da passionalização e da gradação descendente. Percebemos, ainda, que há uma maior identidade entre as unidades entoativas e uma diminuição do uso da tessitura musical. Destaquemos, também, a marcação da divisão rítmica evidenciada pela aliteração “Dou duro toda...”. Assim, a explosão consonantal dos fonemas linguodentais $[t]$ e $[d]$ vai engendrando uma articulação nos modos de integração da canção passionalização-figurativização-tematização. Evidenciemos, ainda, que a aliteração que inicia a modulação do modo de integração temática articula-se à aliteração anterior com o fonema alveolar [s], presente no refrão, iniciado com "No compasso do samba/ Eu disfarço o cansaço/ Joana debaixo do braço...”.

A chegada do objeto, no refrão, é marcada por uma passagem em que temos a concessividade, a disjunção circunstancial frente ao cotidiano relatado. Instalam-se, a partir dessa passagem, novos espaço e tempo, agora, eufóricos: é a transferência 
Linha D'Água (Online), São Paulo, v. 29, n. 2, p. 221-245, dez. 2016

do orador e do auditório a outro espaço e tempo, é a chegada do objeto. No movimento retórico de passagem, percebemos as descendências e as ascendências bruscas e a pouca identidade das unidades entoativas. Podemos notar também uma fuga da melodia instaurada desde o início da canção e, por fim, na finalização da estrofe uma asseveração, enfatizada pela curva melódica descendente, marcada pelo tonema final "aî". O breve trecho traz o efeito da figurativização, da maior presença da gestualidade da fala que irá culminar na tematização.

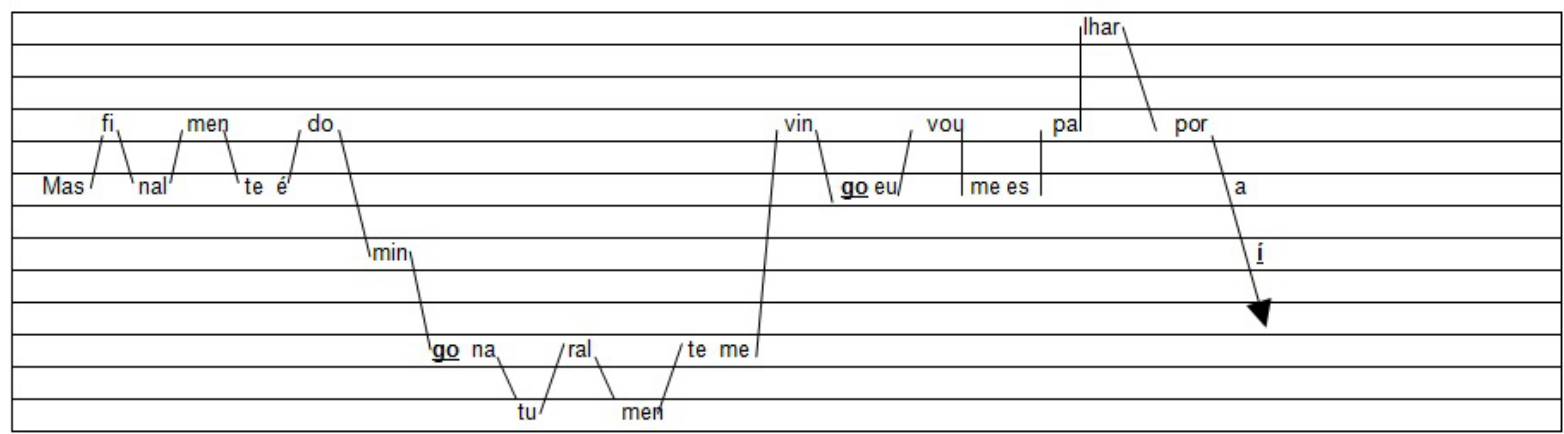

Figura 5

O orador, com a chegada de um espaço e um tempo eufóricos, pode "vingarse", compensando seu cotidiano disfórico. No espaço e tempo eufóricos, o orador possui, além do "saber" anteriormente relatado, um "poder" estar em conjunção com seu objeto "bom tempo". No âmbito da melos, a integração letra e melodia, categorizada como passionalização e, posteriormente, figurativização, faz a passagem do disfórico para o eufórico, dá lugar à integração pela tematização, sobretudo pelo andamento acelerado da melodia. 
Linha D'Água (Online), São Paulo, v. 29, n. 2, p. 221-245, dez. 2016

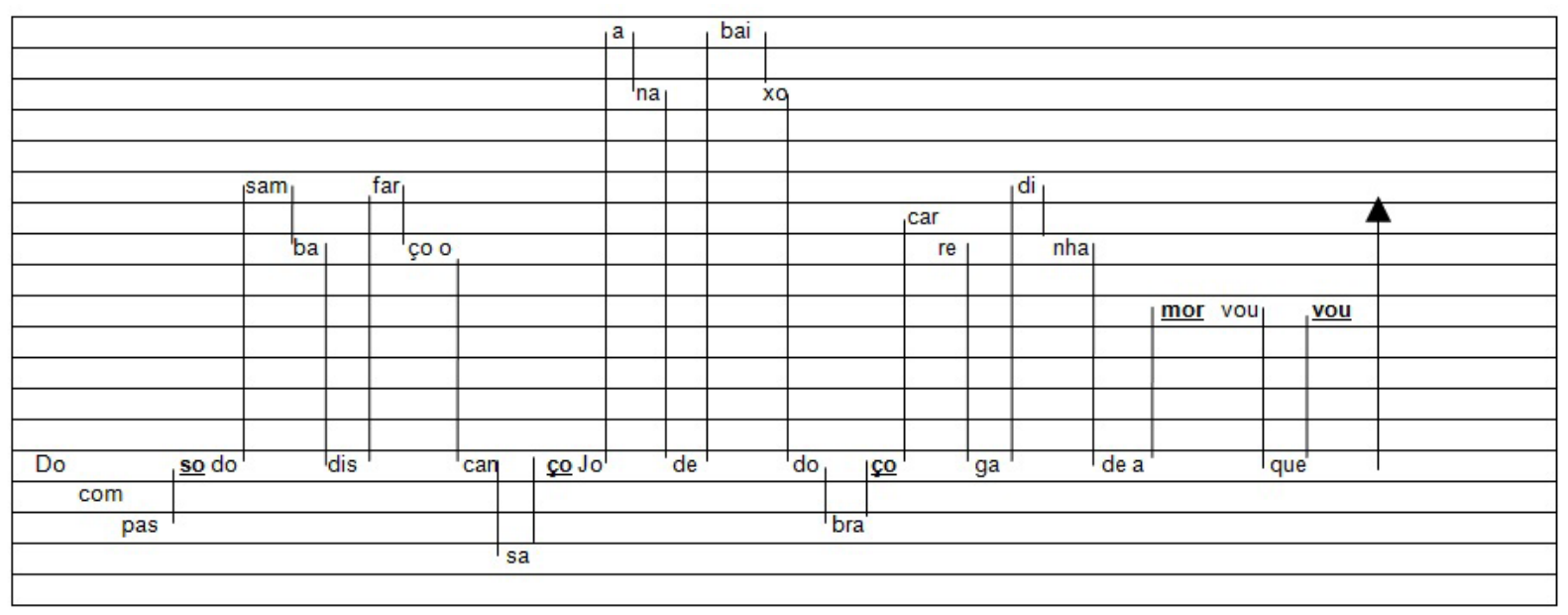

Figura 6

Assim, na configuração do espaço e do tempo eufóricos, no âmbito da melodia, é convocado um novo regime de integração com a letra: a tematização, realizada com a aceleração do andamento da canção e a identidade das unidades entoativas, bem como uma maior densidade musical. Outro fator melódico que nos chama a atenção são as aliterações em que temos, mais uma vez, a ênfase nos fonemas linguodentais [d] e [t], marcando bem a divisão rítmica, em contraste com os fonemas alveolares [s], que os seguem. Articula-se, assim, o engendramento temático da integração letra e melodia. Dessa forma, temos uma sincretização de elementos ratificadores da euforia do novo tempo e espaço instalados.

Destaquemos, ainda no âmbito da melos, a presença dos saltos intervalares. Eles são comuns ao modo de integração passional, da falta, da busca, porém podemos depreender como efeito de sentido desses saltos, não a busca, uma vez que já se está em conjunção com o objeto, mas os efeitos do sobrevir do objeto e a euforia do sujeito na relação com ele.

Por fim, ressaltemos que, a partir de um novo modelo melódico, o orador passa a expor um cotidiano eufórico. As estrofes que compõem a isotopia da euforia terminam em um tonema ascendente, indicando uma prossecução na declaração performativa "vou que vou". 
Linha D'Água (Online), São Paulo, v. 29, n. 2, p. 221-245, dez. 2016

\section{2 "Bom tempo" - Ethos e Pathos}

Após a demonstração da melos articulada ao logos, façamos algumas inferências sobre o ethos e sobre o pathos. Percebemos que o orador constitui um ethos resignado e esperançoso detentor de um saber privilegiado dado por outrem - acerca da chegada do "bom tempo" -, o objeto de desejo é exposto ao auditório por meio de uma axiologização como algo com que se quer estar em conjunção. Dessa forma, apesar de uma condição disfórica apresentada na canção em diversas estrofes, temos a exposição de um espaço e de um tempo eufóricos na perspectiva do devir, que irá sobrevir ao orador-sujeito e ao auditório-sujeito. Essa perspectiva do devir coloca em evidência o pathos da emulação, na esperança, na expectativa do "ainda não é", e da compaixão, tendo como referência a condição disfórica atual dos atores envolvidos no simulacro de anúncio criado.

A partir das análises realizadas, podemos inferir como temas articulados nessa canção a "opressão" (aquilo que já é) tematizada figurativamente pelo "mau tempo" pressuposto e exposto ao assentimento e a "liberdade" tematizada figurativamente pelo andamento do objeto "bom tempo" (não é ainda).

\section{3 "Deus lhe pague" - Logos e Melos}

Outra canção que nos servirá como demonstração da melos como prova retórica de persuasão articulada à trilogia é "Deus lhe pague" de 1971. Esse texto cancional está inserido em um dos períodos mais opressores da ditadura militar. Destaquemos a vigência do AI5, o poder presidencial com o General Médici, autêntico representante da "linha-dura" do regime e o amplo uso de propagandas para legitimar o governo militar e criar uma identidade da população com ele. Esses aspectos evidenciam, ainda mais, o espaço discursivo polêmico do qual a canção faz parte.

Inicialmente, ressaltemos, na introdução da canção, que a instalação do simulacro é realizada musicalmente. Temos o berimbau e o chocalho, instrumentos típicos de rodas de capoeira e de resistência dos escravos brasileiros frente à opressão e à escravidão. Simulacro que figurativiza uma roda de capoeira, um cenário de combatividade no qual se enfrentará um adversário. A percussão também é 
Linha D'Água (Online), São Paulo, v. 29, n. 2, p. 221-245, dez. 2016

responsável por intensificar este simulacro de combatividade, que, a partir de um dado momento na introdução, causa um efeito de sentido temporal, assemelhando-se a um relógio em uma onomatopeia "tic-tac".

Em relação ao título da canção, "Deus lhe pague", trata-se de uma expressão popular utilizada em situações de agradecimento por algo bom que se recebeu ou, também, como expressão de menosprezo à ação recebida ou, até mesmo, como o anúncio de uma revanche, uma vingança. Em nosso caso, trata-se de uma sanção negativa colocada ao fazer de um adversário. Essa expressão opera, também, retoricamente como uma figura de comunhão do orador com o auditório, uma vez que aciona uma memória comum, ou seja, o orador pertence a um grupo que se reconhece no uso linguístico de uma expressão popular.

Há, já no título, a instalação do adversário no embate discursivo "você", realizada pelo pronome oblíquo átono "lhe". Ainda sobre o título da canção, embora seja uma afirmação, fornece uma orientação argumentativa de interrogação, uma vez que deixa pressuposto o objeto pelo qual virá o pagamento divino, a causa do “agradecimento". Essa orientação argumentativa é retomada desde o primeiro verso com construções que reiteram a indagação pressuposta no título; observemos que os versos constituem-se, em geral, por adjuntos adverbiais de causa que se ligam ao verbo "pague" do título e do final de cada estrofe "Por esse pão pra comer/ Por esse chão pra dormir...". Esses adjuntos adverbiais operam como uma rede de anafóricos e de catafóricos, em uma isotopia que traz à tona o adversário "lhe", figura de presença, uma vez que suscita à memória o adversário e o seu fazer. Sobre a configuração melódica, observemos o diagrama a seguir:

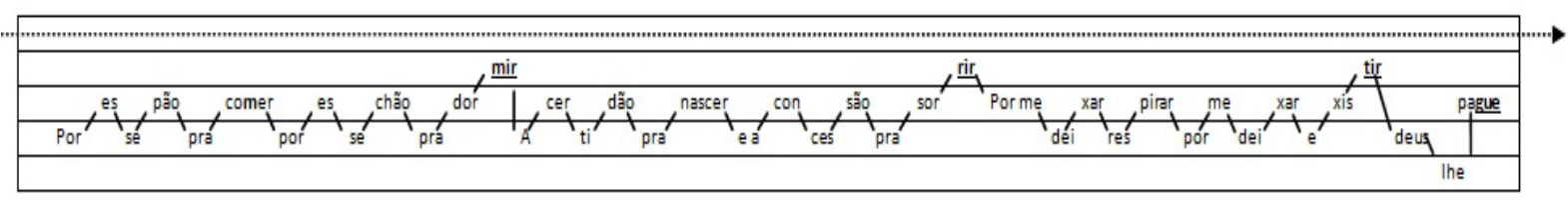

Figura 7

Acerca da integração da letra à melodia, podemos dizer que há um duelo entre um tom e um semitom. Podemos observar, nas unidades entoativas, pequenas ascendências e descendências, num mecanismo de retenção, de concentração 
Linha D'Água (Online), São Paulo, v. 29, n. 2, p. 221-245, dez. 2016

da entoação marcados sempre por meio tom na tessitura musical. Destaquemos, ainda, o tonema, que marca o final da frase musical que revela a dimensão interoceptiva do orador, ressaltando a busca, o esforço de alcançar algo ou o de suportar a configuração disfórica relatada. Notemos o prolongamento das vogais e a ascendência em mais meio tom nos tonemas "mir"; "rir"; "tir". Essa configuração melódica é mantida por toda a canção, havendo apenas uma ascendência em uma oitava posteriormente, que apontaremos a seguir.

A tensão do simulacro instaurado é mantida pelo berimbau e pela percussão, mas também intensificada pela harmonia; as frases musicais são entoadas, em sua maior parte, sob a harmonia de um só acorde ${ }^{1}$, gerando tensão também nesse âmbito. Destaquemos, ainda, o piano, configurando uma maior densidade musical, que aparece, justamente, com os tonemas que possuem maior altura na tessitura musical e também no final de cada estrofe.

Enfatizemos, ainda, a expressão final de cada estrofe, que reitera o título "Deus the pague”. A configuração melódica dessa expressão é marcada por uma descendência no pronome "lhe", que reitera a figura de presença que se refere ao adversário, mantendo-o como um dos tópicos discursivos de que trata o logos. Essa é a configuração melódica que serve de base à canção. Assim, há um princípio de alteridade e de identidade no interior da melodia, ratificado pela letra da canção.

$\mathrm{Na}$ estrofe a seguir, juntamente com o aumento da densidade musical, o número de instrumentos e de elementos musicais utilizados ao mesmo tempo, ocorre um processo de modulação vocal, o aumento do uso da tessitura musical em uma oitava ascendente, permanecendo, porém, o modelo melódico de regime tensivo. Como podemos observar no diagrama a seguir:

Na versão que analisamos, o acorde utilizado na harmonização é o Mi menor. 
Linha D'Água (Online), São Paulo, v. 29, n. 2, p. 221-245, dez. 2016

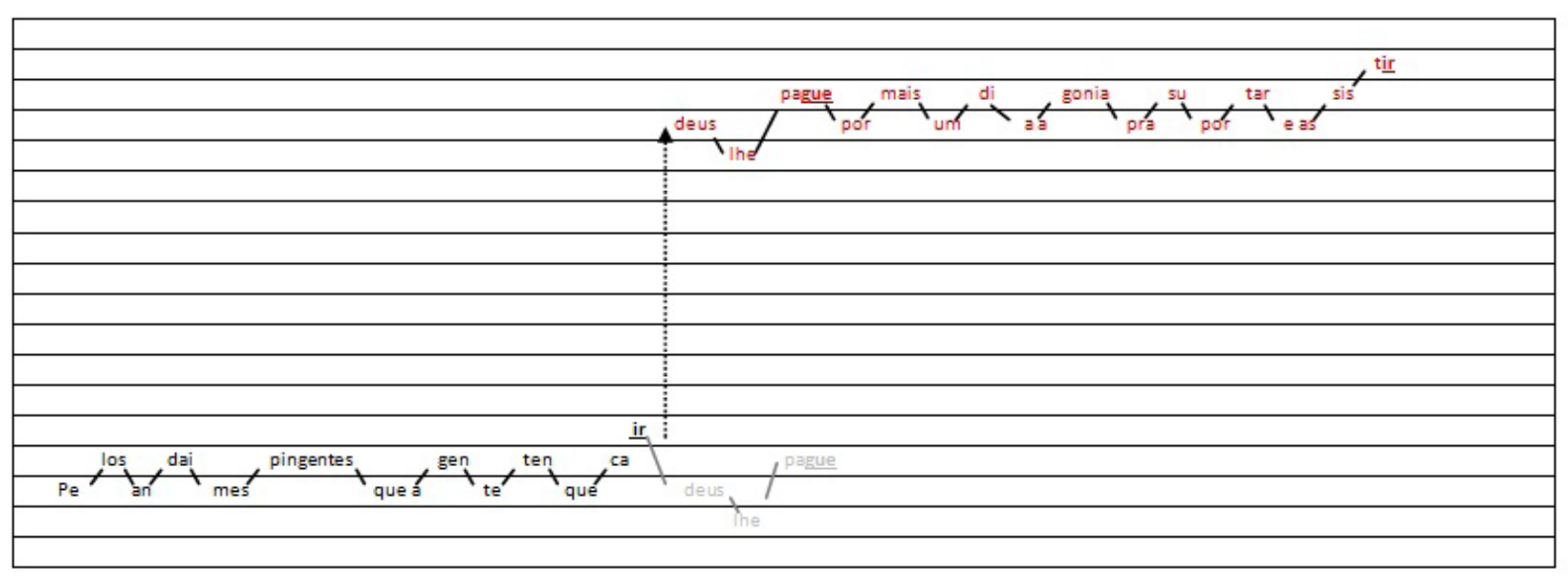

Figura 8

Vale destacar que a partir desse momento da canção a entoação é mantida na oitava superior, conforme demonstramos, como a chegada do embate instaurado a um clímax. Desse modo, sobre as formas de integração de letra e melodia, há uma articulação de duas delas: a passionalização e a figurativização. Temos, por um lado, os tonemas e as unidades entoativas por vezes prolongadas e saltos que exploram a tessitura musical, chegando a uma oitava, ressaltando a busca, a falta, e a dimensão interoceptiva do orador, por outro, uma tendência à gestualidade da fala, o tom de ultimato e de ameaça na modulação vocálica, sobretudo no verso final das estrofes "Deus the pague". A articulação desses modos de integração, passionalização e figurativização, também traz como efeito de sentido uma maior tensividade, uma vez que um regime de integração convoca o outro e a gestualidade da fala é compensada melodicamente pela passionalização a fim de constituir uma canção com entoação musical, mesmo mantendo-se em um campo restrito da tessitura, procedimento que intensifica a tensão na articulação letra e melodia.

\section{4 "Deus lhe pague" - Ethos e Pathos}

O orador constitui por meio do discurso um ethos combativo, reforçando o tom recrudescido utilizado com o adversário "você" na situação retórica cancional. Outro aspecto que pode ser relacionado à constituição do ethos do orador é que, apesar do não "poder", ele é detentor de um "querer" e, sobretudo, de um "saber". O orador busca dar essas competências ao auditório em uma dada perspectiva do estado de coisas, 
Linha D'Água (Online), São Paulo, v. 29, n. 2, p. 221-245, dez. 2016

sobre a opressão (o já) e sobre a liberdade (a espera - o ainda não) a sanção negativa dada ao adversário. $\mathrm{O}$ ethos do orador constrói-se ainda de maneira afetada em sua dimensão passional: ressaltemos a intensidade em que as imposições do adversário sobrevêm ao sujeito, efeitos evidenciados na interlocução do logos e da melos.

A partir dos conteúdos presentes na letra da canção e das análises realizadas, podemos inferir como temas articulados nessa canção a "opressão", (aquilo que (já) é) tematizada, sobretudo pela presença do oponente e pelo seu fazer que impõe uma série de penalidades ao cotidiano do orador e do auditório e a "liberdade" em direção oposta.

Depreendemos, considerando toda a letra da canção, que o ethos, o logos e a melos, articulados, suscitam no auditório as paixões: da cólera, da indignação e da confiança pela reiteração do oponente por uma isotopia temática nas figuras de presença, trazendo à memória do auditório a figura do opressor em uma figurativização de um cotidiano disfórico criado por esse adversário.

\section{Considerações finais}

A melos, conforme expusemos, articula-se às demais provas retóricas ethos, logos e pathos. Pudemos verificar tal possibilidade, tanto pela própria natureza da melos capaz de tocar o campo passional do sujeito que, ao ouvir uma música, pode emocionar-se, alegrar-se ou entristecer-se - quanto pela possibilidade de articulação à trilogia retórica nas canções, ratificando conteúdos, suscitando efeitos de sentido e, por fim, intensificando a mobilização de paixões.

Ressaltemos, ainda, que a melos serve como princípio estruturador e estabilizador do logos, considerando os saltos, as ascendências, as descendências, as gradações, o andamento. Temos, assim, as formas de integração: passionalização, tematização ou figurativização, articulando-se entre si, sincretizando-se à letra das canções e suscitando efeitos de sentido específicos, servindo aos propósitos comunicativos e à própria persuasão.

Ainda na dimensão da melos como prova de persuasão, destaquemos a estabilidade que ela dá aos textos cancionais que podem ser retomados em sua integralidade, seja por meio de uma nova audição da canção, seja, até mesmo, pela ativação 
Linha D'Água (Online), São Paulo, v. 29, n. 2, p. 221-245, dez. 2016

da memória, considerando-se, dessa forma, a melodia como um dispositivo mnemônico dos conteúdos da letra da canção. O texto cancional não se desfaz na clareza como uma linguagem comum em uma prática utilitária, mas permanece em seu plano de expressão, configurando-se como um uso da linguagem semantizado pela melos, acrescentemos, ainda nesse âmbito, a noção de universo musical em que a situação retórica se instaura por meio da canção.

Sobre a relação ethos, logos, pathos e melos, reiteremos que não se isolam, mas se articulam, conforme demonstrado, pois o pathos incide sobre o ethos e sobre o logos, assim como o logos incide sobre o ethos e sobre o pathos, e o ethos incide sobre pathos e sobre o logos. E, por fim, a melos que, em uma situação retórica tomada como cancional, serve como parte do simulacro pela canção instaurado.

Assim, a melos articula-se ao que está sendo tratado, fator que remete ao logos; suscita emoções no auditório, intensifica ou dissipa possíveis efeitos de sentido, fator que remete ao pathos; revela traços constitutivos dos estados de ânimo e da imagem do orador, tomado aqui como o intérprete da canção, a voz que enuncia o texto cancional, fator que remete ao ethos.

A melos configura-se, desse modo, como um elemento fundamental na abordagem à discursividade das canções, na perspectiva interdisciplinar por nós assimilada, como uma quarta prova retórica no texto cancional.

\section{Referências}

ALTHUSSER, Louis. Ideologia e aparelhos ideológicos do Estado: Nota sobre os aparelhos ideológicos do estado. 3. ed. Rio de Janeiro: Graal, 1985.

ARISTÓTELES. Retórica. Tradução de Manuel Alexandre Júnior; Paulo Farmhouse Alberto e Abel do Nascimento Pena. Lisboa: Imprensa Nacional - Casa da Moeda, 1998 [s/d].

CARMO JR., José Roberto do. A voz: entre a palavra e a melodia. In: Teresa: Revista de literatura brasileira. Vol. 4/5. São Paulo: Editora 34, 2003. p. 215-227.

EGGS, Ekkehard. Ethos aristotélico, convicção e pragmática moderna. In: AMOSSY, Ruth (Org.). Imagens de si no discurso, a construção do ethos. São Paulo: Contexto, 2005. 
Linha D'Água (Online), São Paulo, v. 29, n. 2, p. 221-245, dez. 2016

FONSECA, Ísis Borges da. A Retórica na Grécia. In: MOSCA, Lineide do Lago Salvador (Org.). Retóricas de ontem e de hoje. 3. ed. São Paulo: Humanitas, 2001.

FOUCAULT, Michel. A ordem do discurso. 22. ed. Tradução de Laura Fraga de Almeida Sampaio. São Paulo: Loyola, 2012 [1971].

GREIMAS, Algirdas Julio. Semântica estrutural. São Paulo: Cultrix, 1966.

HJELMSLEV, Louis. Prolegômenos a uma teoria da linguagem. São Paulo: Editora Perspectiva, 1971.

LOPES, Ivã Carlos e TATIT, Luiz. Ordem e desordem em fora de ordem. In: Teresa: revista de literatura brasileira. Vol. 4/5. São Paulo: Editora 34, 2003. p. 86-107.

. Elos de Melodia e Letra: análise de seis canções. São Paulo: Ateliê Editorial, 2008.

MEYER, Michel. A Retórica. Trad. Marly Peres. São Paulo: Ática, 2007.

OLIVEIRA, Adriano Dantas. A articulação ethos, logos e pathos: análise sêmio-retórico-discursiva da canção buarquiana "Acorda, amor". In. LUQUES, Solange Ugo; MIRANDA, Daniela da Silveira; PUH, Milan (orgs.). Discurso em suas pluralidades teóricas. São Paulo: Paulistana Editora, 2013. Disponível em: <http//: www.epedusp.com.br>. Acesso em 18.07.2014.

OLIVEIRA, Adriano Dantas. A trilogia retórica asssociada à melos: análise discursiva de canções buarquianas sob o enfoque da tensividade. In. AQUINO, Zilda Gaspar Oliveira de; BENTO, Emilson José. ; OLIVEIRA, Margibel Adriana de; OLIVEIRA, A. D. ; PONTES, Vivian; SANTOS, Thiago Jorge Ferreira. Linguagem, Estratégia e (Re)Construção. São Paulo: Editora Paulistana, 2014. Online: <http//: www.epedusp.com.br>. Acesso em 18.07.2014.

PERELMAN, Chaim; OLBRECHTS-TYTECA, Lucie. Tratado da argumentação: A nova Retórica. Tradução de Maria Ermantina de Almeida Prado Galvão. 2. ed. São Paulo: Martins Fontes, 2005.

TATIT, Luiz. Semiótica da canção: melodia e letra, São Paulo: Editora Escuta, 1994.

O cancionista - composição de canções no Brasil. São Paulo: Edusp, 1996.

. Musicando a Semiótica - ensaios. São Paulo: Annablume, 1997.

OLIVEIRA, A. D. Melos: uma prova retórica nas canções em perspectiva semiótica 
Linha D'Água (Online), São Paulo, v. 29, n. 2, p. 221-245, dez. 2016

. O século da canção. São Paulo: Ateliê Editorial, 2004.

TATIT, Luiz e LOPES, Ivã Carlos. Terra a vista: aportando na canção. Gragoatá: Revista do Instituto de Letras da UFF, Niterói, v. 16. p. 187-208, 2004.

Variedades. São Paulo: Iluminuras, 1991.

Elementos de Semiótica Tensiva. Tradução de Ivã Lopes; Luiz Tatit e Waldir Beividas.

São Paulo: Ateliê Editorial, 2011.

VALERY, Paul. Variedades. São Paulo: iluminuras, 1991.

Recebido em: 27/08/2016.

Aprovado em: 16/09/2016. 